\title{
Using in-situ environmental DNA sampling to detect the invasive New Zealand Mud Snail (Potamopyrgus antipodarum) in freshwaters
}

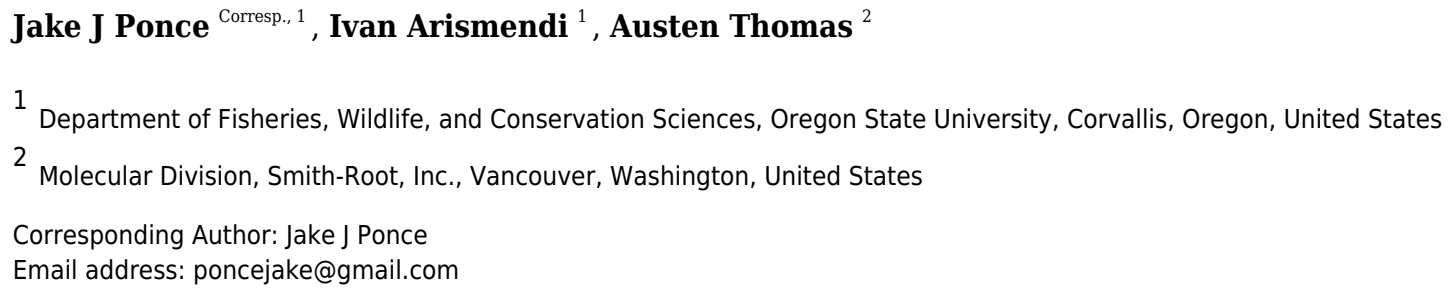

Environmental DNA (eDNA) detection of aquatic invasive species is currently at the forefront of aquatic conservation efforts because the methodology provides a cost effective and sensitive means to detect animals at low densities. Developments in eDNA technologies have improved detection probabilities for rare, indicator, and invasive species over the past decade. However, standard lab analysis can take days or weeks before results are available and is prohibitive when rapid management decisions are required for mitigation. Here, we investigated the performance of a real-time quantitative PCR system for on-site eDNA detection of New Zealand mud snails (Potamopyrgus antipodarum). Six sites in western Washington, USA were sampled using the rapid eDNA technique and traditional methods, with five samples per site. On-site eDNA detection of mud snails resulted in $10 \%$ increase in positive sites $(16 / 30=53 \%$ positive) relative to visual surveys (13/30 $=43 \%$ positive). In addition, positive associations were observed between mud snail eDNA concentration (eDNA copies per reaction) and the number of mud snail individuals at each site $\left(R^{2}=0.78\right)$. We show that the rapid on-site eDNA technology can be effective for detection and quantification of New Zealand mud snails in freshwaters. This on-site eDNA detection approach could possibly be used to initiate management protocols that allow for more rapid responses during the onset of biological invasions. 
1

2

3

4

5

6

7

8

9

10

11

12

13

14

15

16

17

18

19

20

21

22

23

24

25

26

27

28

29

30

31

32

33

34

35

36

37

38

39

40 Corresponding Author: poncejake@gmail.com

(1)

4

6

.

0

1

3

4

26

7

29
8

\section{USING IN-SITU ENVIRONMENTAL DNA SAMPLING TO DETECT THE INVASIVE NEW ZEALAND MUD SNAIL (Potamopyrgus antipodarum) IN FRESHWATERS}

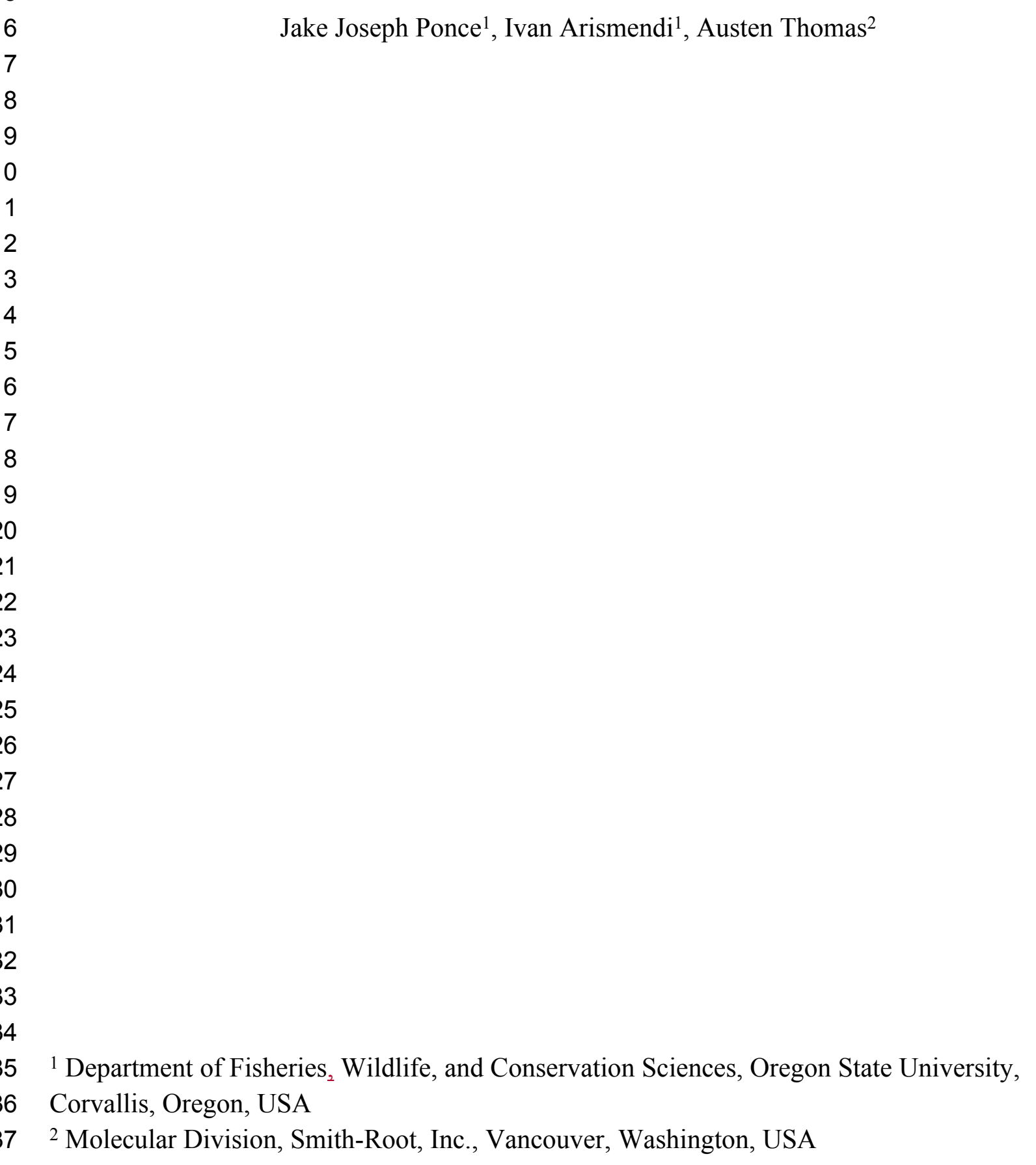

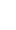

${ }^{1}$ Department of Fisheries, Wildlife, and Conservation Sciences, Oregon State University,

6 Corvallis, Oregon, USA

${ }^{2}$ Molecular Division, Smith-Root, Inc., Vancouver, Washington, USA 


\section{Abstract}

42 Environmental DNA (eDNA) detection of aquatic invasive species is currently at the forefront of 43 aquatic conservation efforts because the methodology provides a cost effective and sensitive 44 means to detect animals at low densities. Developments in eDNA technologies have improved 45 detection probabilities for rare, indicator, and invasive species over the past decade. However, 46 standard lab analysis can take days or weeks before results are available and is prohibitive when 47 rapid management decisions are required for mitigation. Here, we investigated the performance 48 of a real-time quantitative PCR system for on-site eDNA detection of New Zealand mud snails 49 (Potamopyrgus antipodarum). Six sites in western Washington, USA were sampled using the 50 rapid eDNA technique and traditional methods, with five samples per site. On-site eDNA 51 detection of mud snails resulted in $10 \%$ increase in positive sites $(16 / 30=53 \%$ positive $)$ relative 52 to visual surveys $(13 / 30=43 \%$ positive $)$. In addition, positive associations were observed 53 between mud snail eDNA concentration (eDNA copies per reaction) and the number of mud 54 snail individuals at each site $\left(\mathrm{R}^{2}=0.78\right)$. We show that the rapid on-site eDNA technology can 55 be effective for detection and quantification of New Zealand mud snails in freshwaters. This on56 site eDNA detection approach could possibly be used to initiate management protocols that 57 allow for more rapid responses during the onset of biological invasions.

59 Key Words: biological invasions, molecular ecology, streams, non-native snails 60 


\section{Introduction}

64 Aquatic invasive species can dramatically alter native communities by reducing biodiversity and

65 changing ecological processes (Alonso and Castro-Diez 2008). For example, an invasive mollusk

66 the zebra mussel (Dreissena polymorphia), has been known to modify supporting and

67 provisioning services in aquatic ecosystems through alteration of water quality and

68 bioaccumulation of primary production (Vila et al. 2010). In addition, the red swamp crayfish

69 (Procambarus clarkii) one of Europe's top 100 worst invaders has had substantial detrimental

70 impacts on invaded freshwater ecosystems through competition with native species, predation,

71 and alteration of ecosystem services (Lodge et al. 2012; Treguier et al. 2014). Collectively,

72 invasive species can have a large impact on our local and global economy with the United States

73 alone spending roughly $\$ 131-185$ billion dollars per year on invasive species issues (Marbuah et

74 al. 2014).

75 Monitoring for invasive species at all levels of the invasion process (i.e., introduction,

76 establishment, and spread; Kolar and Lodge 2001) can be cost prohibitive. Management teams

77 must balance between the high costs of surveillance and the potential eradication effort that is

78 necessary if there is a failure to detect introduced animals at low abundances (Hayes et al. 2005).

79 Specifically, aquatic invertebrates are notoriously difficult to inventory using traditional

80 sampling methods due to their small size, low population densities, patchy distributions, and the

81 complexity in the use of habitat during different life stages (Barbour et al. 1998). As a result,

82 many bioassessment methods involving identification of taxa only to the genus or family level

83 may be inferior to information collected at the species level when evaluating aquatic

84 management strategies for endangered or non-native species (Mächler et al. 2014). Moreover,

85 traditional sampling methods (i.e., Hess sampler or D-frame kick nets) requires long processing 
86 time, can cause injury to target and non-target species, and prey species are readily exposed to

87 predators after collection (Snyder 2004; Ghani et al. 2016). Conducting these traditional

88 sampling methods can increase the risk of spreading invasions through the transport of sampling

89 gear that have not been properly decontaminated (Bersine et al. 2008; Veldhoen et al. 2016).

Rapid technological advancements including environmental DNA (eDNA) detection has

91 led to increases in sampling sensitivity at a lower cost than traditional sampling (Evans et al.

92 2017). Assessment of biodiversity using eDNA relies on a molecular workflow comprising of

93 several steps including the capture, extraction, and identification of an organism's DNA from

94 environmental samples such as soil or water (Huerlimann et al. 2020). eDNA methods were first

95 applied in sediments, revealing DNA from extinct and extant animals and plants and since then,

96 they have been used to detect taxa from terrestrial and aquatic environments (Thomsen and

97 Willerslev 2015; Coble et al. 2019). eDNA provides an option for detection of species without

98 physical capture or visual confirmation (Davy et al. 2015). Due to rapid emergence of eDNA for

99 detection of flora and fauna, it has generated interest among fisheries and other natural resource

100 managers seeking cost-effective tools for aquatic species inventory and monitoring (Pilliod et al.

101 2013; Coble et al. 2019; Penaluna et al. 2021).

102 Currently, there is not a standardized eDNA sampling protocol for freshwater

103 ecosystems, but the overall sequence of steps includes water collection, preservation, and

104 laboratory analysis (Ruppert et al. 2019). Further, research suggest that sampling decisions made

105 during water collection (i.e., volume of water) and handling step (i.e., on-site vs. lab filtration)

106 may influence detection (Sepulveda et al. 2019; Curtis et al. 2021). Sales et al. (2019) found that

107 samples collected in containers, stored on ice, and then transported back to a lab for filtration

108 yielded higher target species copy numbers than the use of a chemical preservation method. 
109 However, a better approach to maximize DNA concentration is to filter water samples on-site.

110 Indeed, Yamanaka et al. (2016) show that filtering on-site compared to transporting water back

111 to the lab on ice for filtration, yielded 2.21 times more DNA suggesting that immediate filtration

112 could be especially relevant for species that are rare and in low abundances. While eDNA has

113 several advantages to traditional sampling methods, eDNA sampling still requires days, weeks,

114 or even months to receive results depending on the quantity of samples, shipping logistics, and

115 laboratory lead times. Time-sensitive studies or management requirements may have the need for

116 rapid on-site sampling detection processes which could alleviate these complications.

117 Here, we investigate the eDNA field-based platform demonstrated by Thomas et al.

118 (2019) with the Smith-Root eDNA-Sampler and the Biomeme field-portable qPCR thermocycler

119 (hereafter "eDNA field platform") technologies to determine if this method is suitable to provide

120 rapid detection of the non-native New Zealand mud snail (Potamopyrgus antipodarum) in

121 freshwaters. This species is native to New Zealand's freshwater lakes and streams and currently

122 an invasive species to North America (Hall et al. 2003). New Zealand mud snails (hereafter

123 "mud snails") have been documented to exceed in densities greater than 400,000 snails per

124 square meter around Yellowstone National Park (Hall et al. 2003) and found a decade later in the

125 estuary of the Columbia River (Zaranko et al. 1997). Mud snails have continued to spread from

126 the West Coast (Benson et al. 2019) and throughout the world (Schreiber et al. 1998). In this

127 study, we validate the eDNA field platform with traditional field sampling methods in search of

128 mud snails in western Washington, USA. In addition, we explore biologically relevant covariates

129 including snail densities, ambient water temperature, and ambient water conductivity and their

130 association with the relative abundance of mud snail eDNA from water samples. Our study 
131 provides insights to the use of real-time sampling protocols to quickly inform natural resource

132 managers about early detection of biological invasions.

133

134 Materials \& Methods

135 The New Zealand mud snail

136 Mud snails are herbivore/detritivores and were first found in North America in the Middle Snake 137 River in Idaho in 1987 and were thought to have escaped from a fish farm (Bowler 1991; Hall et 138 al. 2003). Mud snails occupy a wide range of habitats, are believed to be a successful invader due 139 to their unique biological features that allow for easy transport to new water bodies and have 140 adaptable reproductive capabilities that have been documented throughout the world (Schreiber 141 et al. 1998). A single female mud snail can produce up to 120 embryos and bear approximately 14270 live individuals every three months (Cheng and LeClair 2011). In their native range, these

143 small gastropods (adults $<5 \mathrm{~mm}$ in length) may reproduce sexually or by parthenogenesis, 144 whereas the non-native populations in North America are known to be all-female clones (Hall et 145 al. 2006). In addition, a shift in nutrient fluxes such as carbon or phosphorus caused by high 146 density populations of mud snails could have a large influence on primary production rates that 147 can affect native grazers and ecosystem functions (Tibbets et al. 2010). Grazing trials conducted 148 with mud snails and native grazers concluded that mud snails were a more efficient grazer 149 (Larson and Black 2016).

With the ability to generate large populations, mud snails can invade ecosystems through 151 varying dispersal methods and have been known to extend its range by over $640 \mathrm{~km}$ along the 152 Snake River, Idaho in as little as ten years (Zaranko et al. 1997). Currently, there is no available 153 method for in situ eradication of mud snails once they invade without harming the entire 
154 ecosystem (Schisler et al. 2008). Minimizing the spread of mud snails include a multitude of

155 efforts and management plans such as educational outreach efforts, chemical application, and

156 mechanical application such as freezing and drying of all encountered field equipment (ANSTF,

157 2006).

158

159 Study Sites

160 We targeted mud snails in western Washington that encompassed a wide range of watersheds

161 and environmental factors to gather a greater representation and variability when comparing the

162 eDNA platform to traditional sampling methods. Our study area consisted of six freshwater

163 streams including Burnt Bridge Creek, Columbia River (Kalama River, WA confluence), Capitol

164 Lake (Deschutes River, WA confluence), May Creek, McAleer Creek, and Thornton Creek (Fig.

165 1). All streams were traditionally surveyed in the past from either Washington Department of

166 Fish and Wildlife or the United States Geological Survey and were confirmed to be positive sites

167 of mud snails with varying relative abundances. Streams were selected based on positive

168 identifications of mud snails, ease of access, and quantity levels of mud snails to compare sites

169 from trace amounts to well established sites.

170 Burnt Bridge Creek, Capitol Lake, and Thornton Creek had a vast amount of aquatic

171 vegetation and soft soil substrates, whereas the Columbia River, May Creek, and McAleer Creek

172 encompassed sand or small cobble sediments. Streams were sampled in May of 2019 to increase

173 probability of detection as seasonal activities and warming temperature conditions can create a

174 reproduction event for mud snails (Schreiber et al. 1998; Ardura et al. 2015). At each stream,

175 sampling occurred along a total length of 40-meters with one eDNA and traditional sample taken

176 every 10-meters. Water samples were obtained first to minimize any contamination from 
177 traditional equipment and all samples started from downstream to upstream direction.

178 Additionally, each sample site was geo-referenced using the internal GPS in the eDNA sampler.

179 Water conductivity and water temperature was also measured in situ using a Hannah Primo 5

180 conductivity meter and HoneForest TDS/Temp meter, respectively.

181

182 Water Sampling

183 The eDNA field platform incorporates a backpack water pump system and a portable handheld

184 qPCR device that allows for field sampling and processing within one hour. The eDNA water

185 sampler technology monitors flow rate, pressure, and volume filtered that can help the user

186 control to the environmental conditions to receive optimal filtration results. A full detail of the

187 eDNA sampler setup and workflow is demonstrated by Thomas et al. (2018). The Biomeme

188 system incorporates a qPCR handheld device that has field ready kits for water samples that

189 come with all the necessary chemistries to extract and run samples for species-specific

190 detections. Further details of the protocols used for both systems are demonstrated by Thomas et

191 al. (2019).

192 We conducted water surface point sampling using the telescoping pole provided to

193 decrease potential contamination from equipment by extending the filter away from the shore.

194 Preliminary sampling at two sites concluded that filters were clogging between $0.75 \mathrm{~L}$ and $2 \mathrm{~L}$,

195 thus samples were standardized to $1 \mathrm{~L}$ per sample with $1 \mathrm{~L} / \mathrm{min}$ flow rate and 12 PSI for pressure.

196 We used single-use filters designed for eDNA water sampling, which are $47 \mathrm{~mm}$ in diameter and

$1975.0 \mu \mathrm{m}$ in pore size made of polyethersulfone filter paper (Sterlitech Corporation). This pump

198 involves a negative pressure system that allows large particulates to descend through the six-inch

199 snorkel tube that is within the water column. After filtration, the filter was kept in the filter

Peer] reviewing PDF | (2020:12:56809:2:0:NEW 27 Jun 2021) 
200 housing and was placed back in the original packaging until all samples were completed at each 201 site ( 20 minutes). We changed nitrile gloves between each eDNA sample filtration to prevent 202 potential cross-contamination. Once all five water samples were obtained, a negative control was 203 filtered using distilled water. These efforts resulted in six samples per stream and a total of 36 204 samples including field blanks. Upon completion of all six field filtrations per stream, samples 205 were taken back to the vehicle where immediate DNA extraction began using the Biomeme 206 extraction kit.

207

208

209 210

211

212 213 214 215 216 217 218

\section{Mobile qPCR}

The portable real-time qPCR thermocycler utilizes shelf-stable ready to go species-specific assay strips and a 5-min DNA extraction kit. The thermocycler has the capability to analyze three DNA samples at a time and in this study, we had one qPCR replicate per water sample. Due to the limited number of wells within this machine we did not include a no-template control, but we did include a field blank at each stream to indicate any cross-contamination issues. The machine has two light channels (FAM and Cy5) and incorporates an internal positive control (IPC) that helps to determine potential inhibition. A standard curve was created by diluting a gBlock (IDT) for mud snails by running four dilutions in the wells comprising of 10, 100, 1,000, and 10,000 copies (Thomas et al. 2018). The limit of detection (LOD) was 10 copies per reaction and the limit of quantification (LOQ) was 50 copies per reaction. Understanding known concentrations can help estimate target DNA concentration values when running unknown samples compared with quantification cycles. We used the mud snail assay, including primer and probe, from Goldberg et al. (2013) with a compatible mastermix that was then ported into the custom pre-loaded freeze-dried pellets that are shelf stable, individually sealed, and ready to be saturated. The M1-field test kit comes with multiple buffers and chemical 
224 solutions where the DNA is bound to a column syringe and is then purified with the various

225 reagents that results in DNA that is ready to be added to the freeze-dried pellets. We followed the

226 manufacturers recommendations for this process, except we added a settling step after the initial

227 lysis buffer stage to help with any inhibition issues and clogging within the syringe. After

228 homogenizing the filter with the lysis buffer, the material was allowed to settle for 15 minutes

229 and then the supernatant liquid was transferred to a new $5 \mathrm{ml}$ vial for the remaining extraction

230 steps. The final step was to use the $20 \mu \mathrm{L}$ micropipette that was included in the kit to then take

231 the purified DNA and transfer to the lyophilized wells to re-hydrate before placing into the

232 machine. We changed nitrile gloves between each DNA extraction to decrease the potential for

233 cross-contamination. Additional details of this process can be found in Thomas et al. (2019).

235 Traditional Field Sampling

236 Each sample site was evaluated by traditional sampling with the same sampling regime from 237 eDNA sampling that incorporated five total samples per location at 10-m increments (for 238 reference see Fig. 2). Traditional sampling of mud snails was conducted after water samples 239 were completed to validate detected and not detected eDNA data to physically identified mud 240 snails to gather an estimated site abundance. At each site, we collected substrate or vegetation 241 depending on the habitat of approximately one square meter by either a D-frame kick net or 242 shovel from the same location where the eDNA sample was taken and placed the material into a $24320 \mathrm{~L}$ bucket. To standardize the effort, we examined the material for $10 \mathrm{~min}$ at each sample site

244 by sifting the material over a number 18 sieve (1.0 mm diameter mesh). Any snails that could not

245 be immediately identified were further examined after $10 \mathrm{~min}$ of sampling effort. We removed 246 captured mud snails from the rivers and took them to the landfill. 


\section{Statistical Analysis}

248 We evaluated the associations between eDNA starting quantity (SQ) or target DNA

249 concentration and environmental covariates including the visual number of mud snails captured,

250 ambient water conductivity, and ambient water temperature using a simple linear regression. Due

251 to limited sample sizes, we combined and averaged values from each stream. Data points were

252 identified for comparisons if the SQ value was greater than the LOQ and positive detections

253 were counted if the SQ was greater than the LOD. To facilitate the visualization of our findings

254 (see raw data as supplement), mud snail DNA copies were grouped and summarized as low $(<$

255133 copies), medium (134-266 copies), and high (> 266 copies). Streams resulting in non-

256 detections for eDNA samples were removed from the analysis. All statistical analyses were

257 conducted using RStudio (2019).

258

259 Results

260 The eDNA field platform successfully detected and quantified DNA concentrations of mud

261 snails from water samples. We were unable to detect mud snails from either sampling method for

262 all six sampling sites in western Washington that were previously surveyed from other agencies

263 who confirmed to have at least one positive snail detection from traditional sampling. At the

264 most upstream sample site in McAleer Creek, we were able to visually identify one mud snail,

265 but did not detect it with the eDNA field platform. However, we detected eDNA at the four

266 samples downstream indicating the importance of both DNA transport and patchy distribution of

267 snails across sample sites. While we only had one field replicate per sample, we included

268 multiple samples per site to increase the likelihood of a positive detection. Inhibition was

269 evaluated by the lack of amplification with the IPC and we observed one sample exhibiting 
270 inhibition equaling a 3\% $(n=30)$ overall field sample inhibition rate (Fig. 2). All control

271 samples resulted in no amplification indicating our contamination sampling protocols were

272 effective in eliminating DNA from other sources. We found that using the eDNA field platform

273 equated to a $10 \%$ increase in detection than traditional sampling (Table 1).

$274 \quad$ For sites with agreement, the results indicate a positive relationship between mud snail

275 DNA copy number per reaction and relative number of mud snail individuals per $\mathrm{m}^{2}\left(\mathrm{R}^{2}=0.78\right.$,

276 Fig. 3a). Similarly, ambient water conductivity showed a positive relationship with the detection

277 of mud snails with eDNA $\left(\mathrm{R}^{2}=0.87\right.$, Fig. $\left.3 \mathrm{~b}\right)$, and water temperature showed a strong

278 association with snail DNA copy number per reaction $\left(\mathrm{R}^{2}=0.73\right.$, Fig. $\left.3 \mathrm{c}\right)$.

279 Mud snail relative abundance was evaluated at sites with positive detections and ordinal 280 data (Fig. 2). Mud snail DNA concentration per reaction was categorized with a low (0-133), 281 medium (134-266), and high (>266) values. Thornton Creek was the only site to observe all three 282 eDNA relative abundance levels within the 40-m sampling distance along the shore and had the 283 highest mud snail DNA concentrations. May Creek had two positive detections within the middle 284 of the sampling section indicating the unique patchy distribution that mud snails can exhibit in 285 small streams.

286

287 Discussion

288 Here, we demonstrate that the eDNA field platform can detect mud snails in rivers of western 289 Washington. At every site where we collected mud snails with traditional sampling, we also 290 detected them with eDNA, except in one sample at McAleer Creek probably owing to low 291 abundances $\left(1.0 \mathrm{snail} / \mathrm{m}^{2}\right)$. New Zealand mud snails can bury themselves within sediments (Duft 292 et al. 2003), making it difficult for them to shed enough DNA for detection with eDNA methods. 
environment and can make surveys whether traditional or eDNA sampling challenging.

Additional water volumes or the use of more replicates can potentially solve this problem to maximize DNA detection. In our case, preliminary filtering at Burnt Bridge Creek under high

20\% more positive sites at McAleer Creek even lacking the one positive detection where we encountered one mud snail. Other field studies that compare traditional sampling techniques to eDNA methods report positive detections at the same site along with visual surveying (Dejean et

al. 2012; Takahara et al. 2013). In some cases, traditional fish snorkeling can be more effective

than eDNA, but this could be due to insufficient water volumes sampled, low densities of the target species, mobility of fish in lotic environments, and eDNA dilution from flowing water

304 (Ulibarri et al. 2017). In other cases, eDNA seems to be more effective in detecting the end of fish distribution in headwater streams than traditional electrofishing techniques (Penaluna et al. 2021). Similarly, our study shows that eDNA has the potential to provide more positive detections of mud snails than traditional sampling. regarding mud snail abundance compared to eDNA except for Goldberg et al. (2013) which evaluated eDNA concentrations and the relationships between mud snail densities in an

312 aquarium and field applications. Similar research has shown eDNA relationships are stronger 313 overall in laboratory settings than compared to field applications (Yates et al. 2019). Though, 314 relationships between relative abundances between eDNA and traditional approaches have been 315 documented for fish, amphibians, and freshwater mollusks (Takahara et al. 2012; Thomsen et al. 
316 2012; Baldigo et al. 2017; Iwai et al. 2019; Stoeckle et al. 2020). For example, Pilliod et al.

317 (2013) shows positive relationships between eDNA and traditional methods for both Rocky

318 Mountain Tailed Frogs (Ascaphus montanus) and Idaho Giant Salamanders (Dicamptodon

319 aterrimus). In other cases, there is no relationship between abundances of eDNA and traditional

320 methods for the Eastern Hellbender Cryptobranchus alleganiensis alleganiensis (Spear et al.

321 2015).

322

We show a positive relationship between water conductivity and mud snail DNA

323 concentrations. This finding can be explained by gastropods generally requiring habitat with high

324 calcium ions, $\mathrm{pH}$, and conductivity (Dillon 2000). Conversely, water temperature conditions

325 resulted in a negative relationship. Temperature conditions from our study sites include suitable

326 ranges for mud snails (Dybdahl and Kane 2005). However, the variability of snail reproduction

327 affected by temperature and eDNA degradation due to warmer waters at two sites may affect our

328 findings (Strickler et al. 2015; de Souza et al. 2016).

329 The use of eDNA as well as our approach have some limitations to consider. For

330 example, PCR inhibition occurs under high concentration of organic compounds that includes

331 humic and fulvic acids (Wetzel 1992; Albers et al. 2013; McKee et al. 2015). eDNA can also be

332 degraded by distance traveled, $\mathrm{pH}$, and UV radiation inducing false negatives (Jane et al. 2015;

333 Klymus et al. 2015; Strickler et al. 2015). It is recommended that for early detection surveys,

334 additional replicates are included when results are positive to confirm presence or when false

335 negatives may occur due to low abundances (Rees et al. 2014; Goldberg et al. 2016; Clusa et al.

336 2017). In our study, the use of one replicate is a limitation, however, our approach incorporates

337 additional samples within the same proximity $(40 \mathrm{~m})$ which increases our chances of detection

338 given the patchy distribution of mud snails. We encourage further research to consider mud 
339 snail-specific study designs before any broader survey implementation. We did our best to

340 minimize our study limitations by including filtration and DNA extraction in situ. Specifically,

341 we decrease the prevalence of inhibitors by using a negative pressure pump system that helps to

342 decrease large particulates on the filter membrane and elimination of sample preservation. The

$3433 \%$ inhibition rate in our study is comparable to Nguyen et al. (2018) and lower than others

344 (Sepulveda et al. 2018; Thomas et al. 2019). We incorporated a settling step to decrease PCR

345 inhibition over space, however, further refinement may be needed pending different

346 environmental conditions and or a pilot study to confirm sampling protocols.

347 Early detection of species in low numbers or that are elusive such that of non-native

348 species using eDNA is critical for managers to respond with the best strategy to prevent

349 environmental degradation (Pluess et al. 2012; Anglès et al. 2019; Penaluna et al. 2021). There

350 are still many questions about best practices of using eDNA to detect invasive species in

351 freshwaters. For example, eDNA production rates can vary among differing species, densities,

352 age classes, and seasonal changes (Maruyama et al. 2014; Sassoubre et al. 2016). In streams,

353 transport, settling, and dilution can affect detection probabilities and is documented that eDNA

354 detections can occur up to $12 \mathrm{~km}$ downstream (Deiner and Altermatt 2014). Understanding the

355 habitat and species-specific environmental traits where eDNA sampling is conducted will help

356 natural resource managers choose specific sampling strategies to be deployed to increase success

357 in early detection of invasive species.

358

\section{Conclusions}

360 We show that the eDNA field platform used here can detect mud snails within a rapid response

361 time $(\sim 1 \mathrm{~h})$. This equipment is less expensive for long-term management practices, does not 
362 require lab-based equipment or specialized personnel to manipulate samples and report results.

363 Utilizing the eDNA field platform is a promising tool for natural resource managers tool bags for

364 battling the forefront of aquatic invasions.

365

366 Acknowledgements.

367 Jesse Schultz from Washington Department of Fish and Wildlife for providing the locations of

368 the animals and Mieke Sinnesael from Biomeme, Inc. for her input and technical help with the 369 qPCR equipment. Also, would like to thank Drew Carey for his assistance with GIS. Two

370 anonymous reviewers, Shaun Wilkinson, and the Associated Editor, Xavier Pochon, provided

371 excellent suggestions to improve our final version of this manuscript.

372

373

374

375

376

377

378

379

380

381

382

383

384

385

386

387

388

389

390

391

392

393

394 
395

396

397

398

399

400

401

402

403

404

405

406

407

408

409

410

411

412

413

414

415

416

417

418

\section{References}

Albers, C. N., A. Jensen, J. Baelum, and S. Jacobsen. 2013. Inhibition of DNA polymerases used in q-PCR by structurally different soil-derived humic substances. Geomicrobiology Journal 30(8):675-681.

Alonso, A., and P. Castro-Diez. 2008. What explains the invading success of the aquatic mud snail Potamopyrgus antipodarum (Hydrobiidae, Mollusca). Hydrobiologia 614(1):107116.

Anglès d'Auriac, M. B., D. A. Strand, M. Mjelde, B. O. L. Demars, and J. Thaulow. 2019. Detection of an invasive aquatic plant in natural water bodies using environmental DNA. Plos One 14(7):e0219700.

Aquatic Nuisance Species Task Force (ANSTF). 2006. National management and control plan for the New Zealand mudsnail. (Potamopyrgus antipodarum). Available: Www.anstaskforce.gov/.

Ardura, A., A. Zaiko, J. L. Martinez, A. Samulioviene, A. Semenova, and E. Garcia-Vazquez. 2015. eDNA and specific primers for early detection of invasive species - a case study on the bivalve Rangia cuneate, currently spreading in Europe. Marine Environmental Research 112: 48-55.

Baldigo, B. P., L. A. Sporn, S. D. George, and J. A. Ball. 2017. Efficacy of environmental DNA to detect and quantify brook trout populations in headwater streams of the Adirondack Mountains, New York. Transactions of the American Fisheries Society 146(1):99-111. Taylor \& Francis.

Barbour, M. T., J. Gerritsen, B. D. Snyder, and J. B. Stribling. 1998. USEPA rapid bioassessment protocols for use in streams and wadeable Rivers, 1-35. 
419 Benson, A. J., R. M. Kipp, J. Larson, and A. Fusaro. 2019. Potamopyrgus antipodarum (J.E.

420 Gray, 1853): U.S. Geological Survey, nonindigenous aquatic species database,

421 Gainesville, FL. https://nas.er.usgs.gov/queries/factsheet.aspx?SpeciesID=1008, Revision

422 Date: 9/13/2019.

423

424

425

426

427

428

429

430

431

432

433

434

435

436

437

438

439

440

441

Bersine, K., V. E. F. Brenneis, R. C. Draheim, A. M. W. Rub, J. E. Zamon, R. K. Litton, and J. W. Chapman. 2008. Distribution of the invasive New Zealand mudsnail (Potamopyrgus antipodarum) in the Columbia River estuary and its first recorded occurrence in the diet of juvenile Chinook salmon (Oncorhynchus tshawytscha). Biological Invasions 10(8):1381-1388.

Bowler, P. A. 1991. The rapid spread of the freshwater hydrobiid snail Potamopyrgus antipodarum (gray) in the middle Snake River, Southern Idaho. Proceeding of the Desert Fishes Council 21:173-182.

Cheng, Y. M. and L. L. LeClair. 2011. A quantitative evaluation of the effect of freezing temperatures on the survival of New Zealand mud snails (Potamopyrgus antipodarum) in Olympia Washington's Capitol Lake. Aquatic Invasions 6(1):47-54.

Clusa, L., L. Miralles, A. Basanta, C. Escot, and E. García-Vázquez. 2017. eDNA for detection of five highly invasive molluscs. A case study in urban rivers from the Iberian Peninsula. PLoS one 12(11):1-14.

Coble, A. A., C. A. Flinders, J. A. Homyack, B. E. Penaluna, R. C. Cronn, and K. Weitemier. 2019. eDNA as a tool for identifying freshwater species in sustainable forestry: A critical review and potential future applications. Science of Total Environment 649:1157-1170.

Curtis, A. N., E. R. Larson, and M. A. David. 2021. Field storage of water samples affects measured environmental DNA concentration and detection. Limnology 22:1-4. 
442 Davy, C. M., A. G. Kidd, and C. C. Wilson. 2015. Development and validation of environmental

443

444

445

446

447

448

449

450

451

452

453

454

455

456

457

458

459

460

461

462

463

464 DNA (eDNA) markers for detection of freshwater turtles. PLoS ONE 10(7): e0130965.

Dejean, T., A. Valentini, C. Miquel, P. Taberlet, E. Bellemain, and C. Miadu. 2012. Improved detection of an alien invasive species through environmental DNA barcoding: the example of the American bullfrog Lithobates catesbeianus. Journal of Applied Ecology 49: 953-959.

Deiner, K. and F. Altermatt. 2014. Transport distance of invertebrate environmental DNA in a natural river. PLoS ONE 9(2): e88786.

de Souza, L. S., J. C. Godwin, M. A. Renshaw, and E. Larson. 2016. Environmental DNA (eDNA) detection probability is influenced by seasonal activity of organisms. PLos ONE 11(10):e0165273.

Dillon, R. T. 2000. The Ecology of Freshwater Molluscs. Cambridge University Press.

Duft, M., U. Schulte-Oehlmann, M. Tillmann, B. Markert, and J. Oehlmann. 2003. Toxicity of triphenyltin and tributyltin to the freshwater mudsnail (Potamopyrgus antipodarum) in a new sediment biotest. Environmental Toxicology and Chemistry 22:145-152.

Dybdahl, M. F., and S. L. Kane. 2005. Adaptation vs. phenotypic plasticity in the success of a clonal invader. Ecology 86(6):1592-1601.

Evans, N. T., P. D. Shirey, J. G. Wieringa, A. R. Mahon, and G. A. Lamberti. 2017. Comparative Cost and Effort of Fish Distribution Detection via Environmental DNA Analysis and Electrofishing. Fisheries 42(2):90-99.

Ghani, W. M., C. S. Rawi, S. A. Hamid, and S. A. Al-Shami. 2016. Efficiency of different sampling tools for aquatic macroinvertebrate collections in Malaysian streams. Tropical Life sciences research 27(1):115-133. 
465 Goldberg, C. S., A. Sepulveda, A. Ray, J. Baumgardt, and L. P. Waits, L. P. 2013.

466 Environmental DNA as a new method for early detection of New Zealand mudsnails

467 (Potamopyrgus antipodarum). Freshwater Science 32(3):792-800.

468 Goldberg, C. S., C. R. Turner, K. Deiner, K. E. Klymus, P. F. Thomsen, M. A. Murphy, S. F. 469 Spear, A. McKee, S. J. Oyler-McCance, R. S. Cornman, M. B. Laramie, A. R. Mahon, R. F. Lance, D. S. Pilliod, K. M. Strickler, L. P. Waits, A. F. Fremier, T. Takahara, J. E. Herder, and P. Taberlet. 2016. Critical considerations for the application of environmental DNA methods to detect aquatic species. Methods in Ecology and Evolution 8:1299-1307.

Hall, R. O., J. Tank, and M. Dybdahl. 2003. Exotic snails dominate nitrogen and carbon cycling 475 in a highly productive stream. Frontiers in Ecology and the Environment 1(8):407-411.

Hall, R. O., M. F. Dybdahl, and M. C. VanderLoop. 2006. Extremely high secondary production of introduced snails in rivers. Ecol Appl 16:1121-1131.

Hayes, K. R., R. Cannon, K. Neil, and G. Inglis. 2005. Sensitivity and cost considerations for the detection and eradication of marine pests in ports. Marine Pollution Bulletin 5:823-834.

480

481

482

483

484 485

Huerlimann, R., M. K. Cooper, R. C. Edmunds, C. Villacorta-Rath, A. Le Port, H. L. A. Robson, J. M. Strugnell, D. Burrows, and D. R. Jerry. 2020. Enhancing tropical conservation and ecology research with aquatic environmental DNA methods: an introduction for nonenvironmental DNA specialists. Animal Conservation 23:632-645.

Iwai, N., K. Yasumiba, and T. Takahara. 2019. Efficacy of environmental DNA to detect and quantify stream tadpoles of Odorrana splendida. Royal Society Open Science 6:181798. 
486 Jane, S. F., T. M. Wilcox, K. S. Mckelvey, M. K. Young, M. K. Schwartz, W. H. Lowe, B. H. 487 Letcher, and A. R. Whiteley. 2015. Distance, flow and PCR inhibition: eDNA dynamics 488 in two headwater streams. Molecular Ecology Resources 15(1):216-227.

489 Kolar, C. S., and D. M. Lodge. 2001. Progress in invasion biology: predicting invaders. Trends 490 in Ecology and Evolution 16:199-204.

491 Klymus, K. E., C. A. Richter, D. C. Chapman, and C. Paukert. 2015. Quantification of eDNA 492 shedding rates from invasive bighead carp Hypophthalmichthys nobilis and silver carp 493 Hypophthalmichthys molitrix. Biological Conservation 183:77-84.

Larson, M. D., and R. Black. 2016. Assessing interactions among native snails and the invasive New Zealand mud snail, Potamopyrgus antipodarum, using grazing experiments and stable isotope analysis. Hydrobiologia 763(1):147-159.

497

498

499

500

501

502

503

504

505

506

Lodge, D.M., A. Deines, F. Gherardi, D. C. J. Yeo, T. Archella, A. K. Baldridge, M. A. Barnes, W. L. Chadderton, J. L. Feder, C. A. Gantz, G. W. Howard, C. L. Jerde, B. W. Peters, J. A. Peters, L. A. Sargent, C. R. Turner, M. E. Whittmann, and Y. Zeng. 2012. Global introductions of crayfishes: Evaluating the impact of species invasions on ecosystem services. Annual Review of Ecology, Evolution, and Systematics 43:449-472.

Mächler, E., K. Deiner, P. Steinmann, and F. Altermatt. 2014. Utility of environmental DNA for monitoring rare and indicator macroinvertebrate species. Freshwater Science 33:11741183._http://doi.org/10.1086/678128.

Marbuah, G., I. M. Gren, and B. McKie. 2014. Economics of harmful invasive species: a review. Diversity 6(3):500-523. 
507 McKee, A. M., S. F. Spear, and T. W. Pierson. 2015. The effect of dilution and the use of a post508 extraction nucleic acid purification column on the accuracy, precision, and inhibition of 509 environmental DNA samples. Biological Conservation 183:70-76.

510 Maruyama, A., K. Nakamura, H. Yamanaka, M. Kondoh, and T. Minamoto. 2014. The release of 511 environmental DNA from juvenile and adult fish. PLoS ONE 9(12):e114639.

512 Nguyen, P. L., P. S. Sudheesh, A. C. Thomas, M. Sinnesael, K. Haman, K. D. Cain. 2018. Rapid 513 514 515 516 517 518 detection and monitoring of Flavobacterium psychrophilum in wąáter by using a handheld, field-portable quantitative PCR system. Journal of Aquatic Animal Health 30:302-311.

Penaluna, B.E., J. M. Allen, I. Arismendi, T. Levi, T. S. Garcia, and J. K. Walter. 2021. Better Boundaries: identifying the upper extent of fish distributions in forested streams using eDNA and electrofishing. Ecosphere 12(1):e03332.

Pilliod, D. S., C. S. Goldberg, R. S. Arkle, L. P. Waits, and J. Richardson. 2013. Estimating occupancy and abundance of stream amphibians using environmental DNA from filtered water samples. Canadian Journal of Fisheries and Aquatic Sciences 70(8):1123-1130. http://doi.org/10.1139/cjfas-2013-0047.

Pluess, T., V. Jarošík, P. Pyšek, R. Cannon, J. Pergl, A. Breukers, and S. Bacher. 2012. Which Factors Affect the Success or Failure of Eradication Campaigns against Alien Species? PLoS ONE 7(10):e48157.

Rees, H. C., B. C. Maddison, D. J. Middleditch, J. R. M. Patmore, and K. C. Gough. 2014. The 527 detection of aquatic animal species using environmental DNA - A review of eDNA as a survey tool in ecology. Journal of Applied Ecology 51:1450-1459. 
529 Ruppert, K. M., R. J. Kline, and M. S. Rahman. 2019. Past, present, and future perspectives of

530

531

532

533

534

535

536

537

538

539

540

541

542

543

544

545

546

547

548

549

550

environmental DNA (eDNA) metabarcoding: A systematic review in methods, monitoring, and applications of global eDNA. Global Ecology and Conservation 17:e0547.

Sales, N. G., O. S. Wangensteen, D. C. Carvalho, and S. Mariani. 2019. Influence of preservation methods, sample medium and sampling time on eDNA recovery in a neotropical river. Environmental DNA 1(2):119-130.

Sassoubre, L. M., K. M. Yamahara, L. D. Gardner, B. A. Block, and A. B. Boehm. 2016. Quantification of environmental DNA (eDNA) shedding and decay rates for three marine fish. Environmental Science \& Technology 50:10456-10464.

Schisler, G. J., N. K. M. Vieira, and P. G. Walker. 2008. Application of household disinfectants to control New Zealand mudsnails. North American Journal of Fisheries Management 28:1172-1176.

Schreiber, E. S. G., A. Glaister, G. P. Quinn, and P. S. Lake. 1998. Life history and population dynamics of the exotic snail Potamopyrgus antipodarum (Prososbranchia: Hydrobiidae) in Lake Purrumbete, Victoria, Australia. Marine Freshwater Research 49:73-78.

Sepulveda, A. J., P. R. Hutchins, R. L. Massengill, and K. J. Dunker. 2018. Tradeoffs of a portable, field-based environmental DNA platform for detecting invasive northern pike (Esox lucius) in Alaska. Management of Biological Invasions 9(3):253-258.

Sepulveda, A. J., J. Schabacker, S. Smith, R. Al-Chokhachy, G. Luikart, and S. J. Amish. 2019. Improved detection of rare, endangered and invasive trout in using a new large-volume sampling method for eDNA capture. Environmental DNA 1:227-237.

Peer) reviewing PDF | (2020:12:56809:2:0:NEW 27 Jun 2021) 
551 Snyder, D. E. 2004. Invited overview: Conclusions from a review of electrofishing and its

552 harmful effects on fish. Reviews in Fish Biology and Fisheries 13(4): 445-453.

553 Spear, S. F., J. D. Groves, L. A. Williams, and L. P. Waits. 2015. Using environmental DNA

554 methods to improve detectability in a hellbender (Cryptobranchus alleganiensis)

555 monitoring program. Biological Convservation 183:38-45.

556 Stoeckle, B. C., S. Beggel, R. Kuehn, and J. Geist. 2020. Influence of stream characteristics and 557 population size on downstream transport of freshwater mollusk environmental DNA. The

558 Society of Freshwater Science 40(1):191-201.

559 Strickler, K. M., A. K. Fremier, and C. S. Goldberg. 2015. Quantifying effects of UV-B,

560 temperature, and $\mathrm{pH}$ on eDNA degradation in aquatic microcosms. Biological

561 Conservation 183:85-92.

562

Takahara, T., T. Minamoto, H. Yamanaka, H. Doi, and Z. Kawabata. 2012. Estimation of fish 563 biomass using environmental DNA. PloS one 7:e35868.

564

Takahara, T., T. Minamoto, and H. Doi. 2013. Using Environmental DNA to Estimate the 565 Distribution of an Invasive Fish Species in Ponds. PLoS ONE 8(2):e56584.

566 Thomas, A. C., J. Howard, P. L. Nguyen, T. A. Seimon, and C. S. Goldberg. 2018. eDNA 567 Sampler: A fully integrated environmental DNA sampling system. Methods in Ecology and Evolution 9(6):1379-1385.

569

Thomas, A. C., S. Tank, P. L. Nguyen, J. Ponce, M. Sinnesael, and C. S. Goldberg. 2019. A

570 system for rapid eDNA detection of aquatic invasive species. Environmental DNA 00:1-

571 10. 
572 Thomsen, P. F., J. Kielgast, L. L. Iversen, C. Wiuf, M. Rasmussen, M. T. P. Gilbert, L. Orlando, 573 and E. Willerslev. 2012. Monitoring endangered freshwater biodiversity using 574 environmental DNA. Molecular Ecology 21(11):2565-2573.

575 Thomsen, P. F., and E. Willerslev. 2015. Environmental DNA - An emerging tool in 576 conservation for monitoring past and present biodiversity. Biological Conservation $577 \quad 183: 4-18$.

578 Tibbets, M. T., A. C. Krist, R. O. Hall, and L. A. Riley. 2010. Phosphorus-mediated changes in 579 life history traits of the invasive New Zealand mudsnail (Potamopyrgus antipodarum). $580 \quad$ Oecologia 163:549-559.

581 Treguier, A., J. Paillisson, T. Dejean, A. Valentini, M. A. Schlaepfer, and J. Roussel. 2014. 582 Environmental DNA surveillance for invertebrate species: advantages and technical 583 limitations to detect invasive crayfish Procambarus clarkia in freshwater ponds. Journal of Applied Ecology 51:871-879.

585

586

587

588

589 590

591

592

593

Ulibarri, R. M., S. A. Bonar, C. Rees, J. Amberg, B. Ladell, C. Jackson. 2017. Comparing efficiency of American fisheries society standard snorkeling techniques to environmental DNA sampling techniques. North American Journal of Fisheries Management 37:644651.

Veldhoen, N., J. Hobbs, G. Ikonomou, M. Hii, M. Lesperance, and C. C. Helbing. 2016. Implementation of novel design features for qpcr-based eDNA assessment. PLoS ONE 11(11):1-23.

Vila, M., C. Basnou, P. Pysek, M. Josefsson, P. Genovesi, S. Gollasch, W. Nentwig, S. Olenin, A. Roques, D. Roy, and P. E. Hulme. 2010. How well do we understand the impacts of 
594

595

596

597

598

599

600

601

602

603

604

605

606

607

608

609 alien species on ecosystem service? A pan-European, cross-taxa assessment. Frontiers in Ecology and the Environment 8(3):135-144. doi:10.1890/080083.

Wetzel, R.G. 1992. Gradient-dominated ecosystems: sources and regulatory functions of dissolved organic matter in freshwater ecosystems. In: Dissolved Organic Matter in Lacustrine Ecosystems. Springer, pp. 181-198.

Yamanaka, H., H. Motozawa, S. Tsuji, R. C. Miyazawa, T. Takahara, and T. Minamoto. 2016. On-site filtration of water samples for environmental DNA analysis to avoid DNA degradation during transportation. Ecological Research 31(6):963-967.

Yates, M. C., D. J. Fraser, and A. M. Derry. 2019. Meta-analysis supports further refinement of eDNA for monitoring aquatic species-specific abundance in nature. Environmental DNA $1: 5-13$.

Zaranko, D. T., Farara, D. G., \& Thompson, F. G. 1997. Another exotic mollusc in the Laurentian Great Lakes: The New Zealand native Potamopyrgus antipodarum (Gray 1843) (Gastropoda, Hydrobiidae). Canadian Journal of Fisheries and Aquatic Sciences, 54(4):809-814. 
Figure 1

Sampling area.

Map including the six sampling sites in Washington State, United States. 


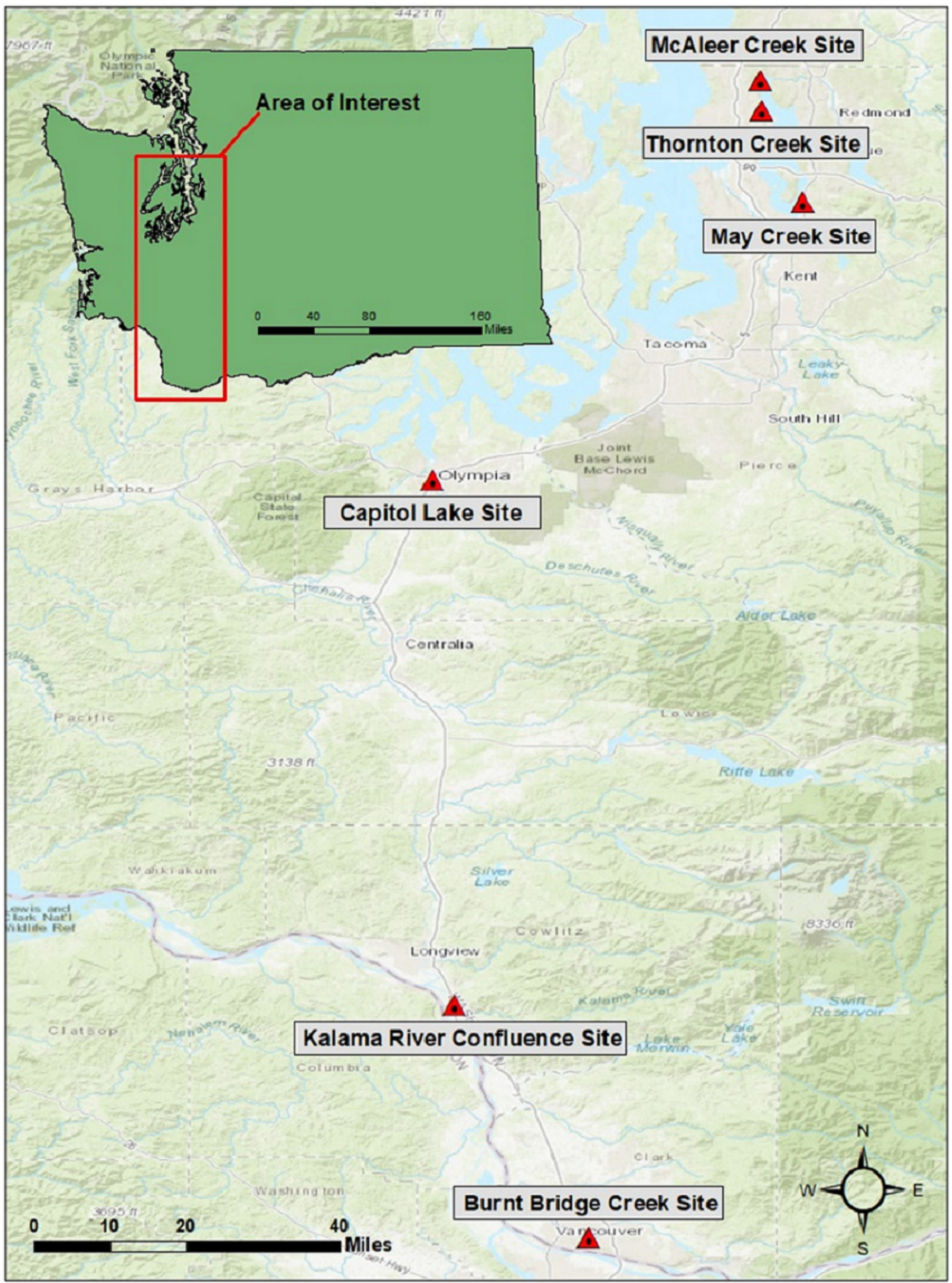


Figure 2

Summary of eDNA sampling array per site.

Target eDNA copy numbers per reaction is represented by Low $=0-133$, Med $=134-266$, and High $>266$. The asterisk denotes PCR inhibition. 


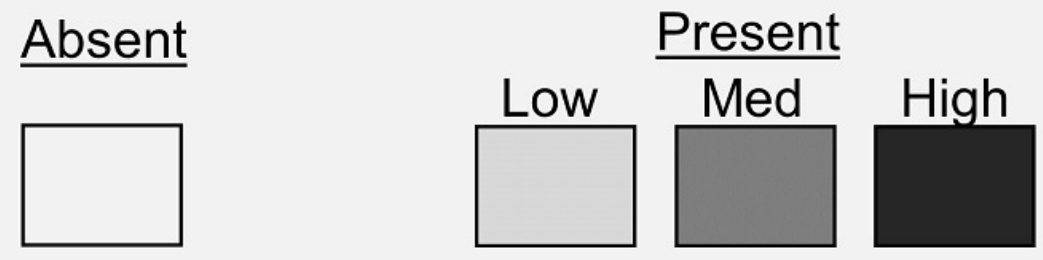

Flow of Stream

Sample 1 Sample 2 Sample 3 Sample $4 \quad$ Sample 5

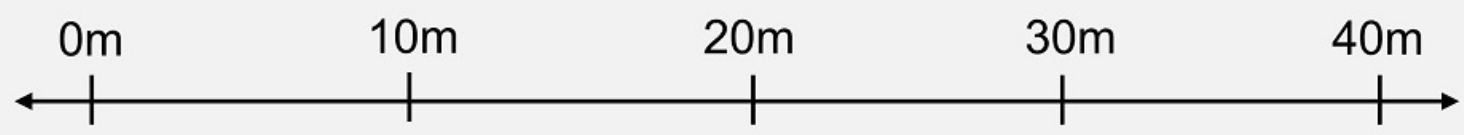

\section{Burnt Bridge Creek}

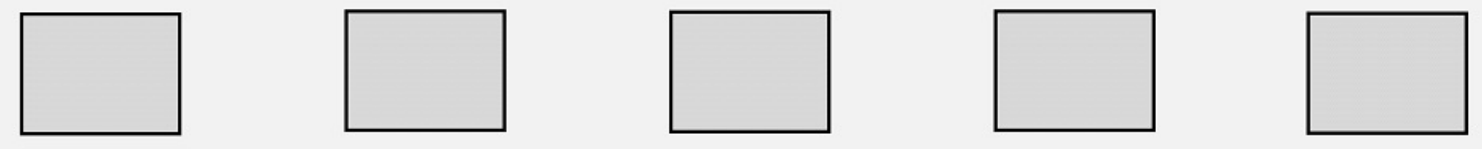

Columbia River (Kalama)
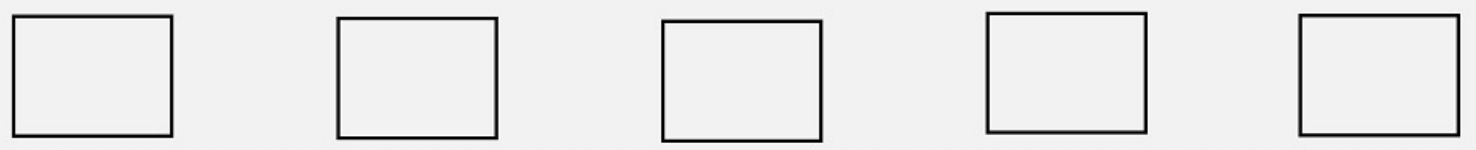

Capitol Lake

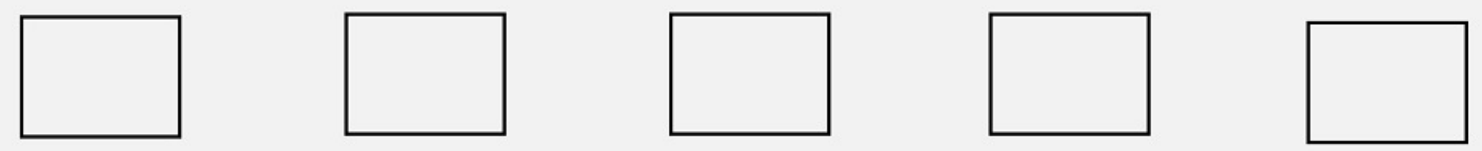

May Creek

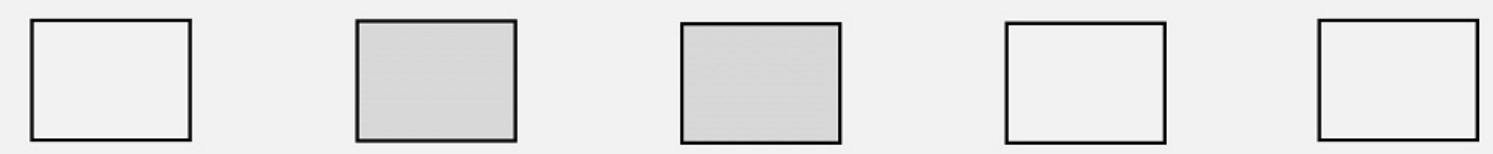

McAleer Creek

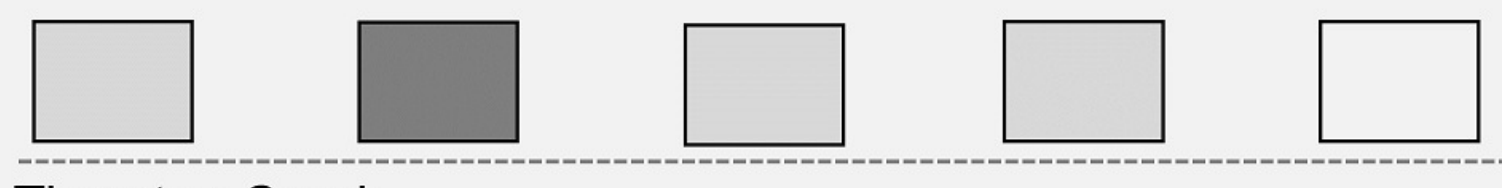

Thornton Creek

\section{*}
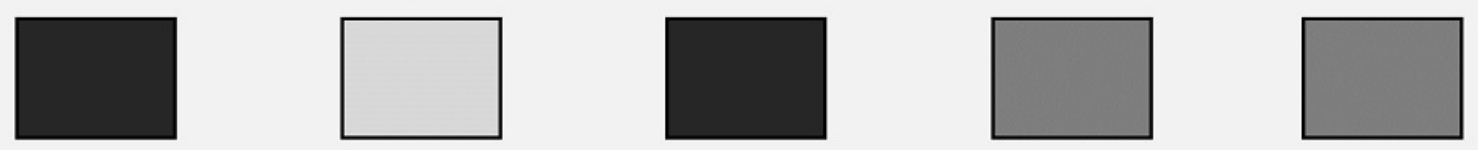


\section{Figure 3}

Relationship between New Zealand mud snails (Potamopyrgus antipodarum) eDNA abundance (copies per reactions) and environmental covariates at the six streams sampled.

(A) number of captured mud snails $\left(R^{2}=0.78\right)$; (B) ambient water conductivity $(\mu \mathrm{S} / \mathrm{cm})-2$ streams had no eDNA detections in all samples $\left(R^{2}=0.87\right)$; $(C)$ ambient water temperature $\left({ }^{\circ} \mathrm{C}\right)$ - 2 streams had no eDNA detections in all samples $\left(R^{2}=0.73\right)$. Dotted lines indicate $95 \%$ confidence bands. 


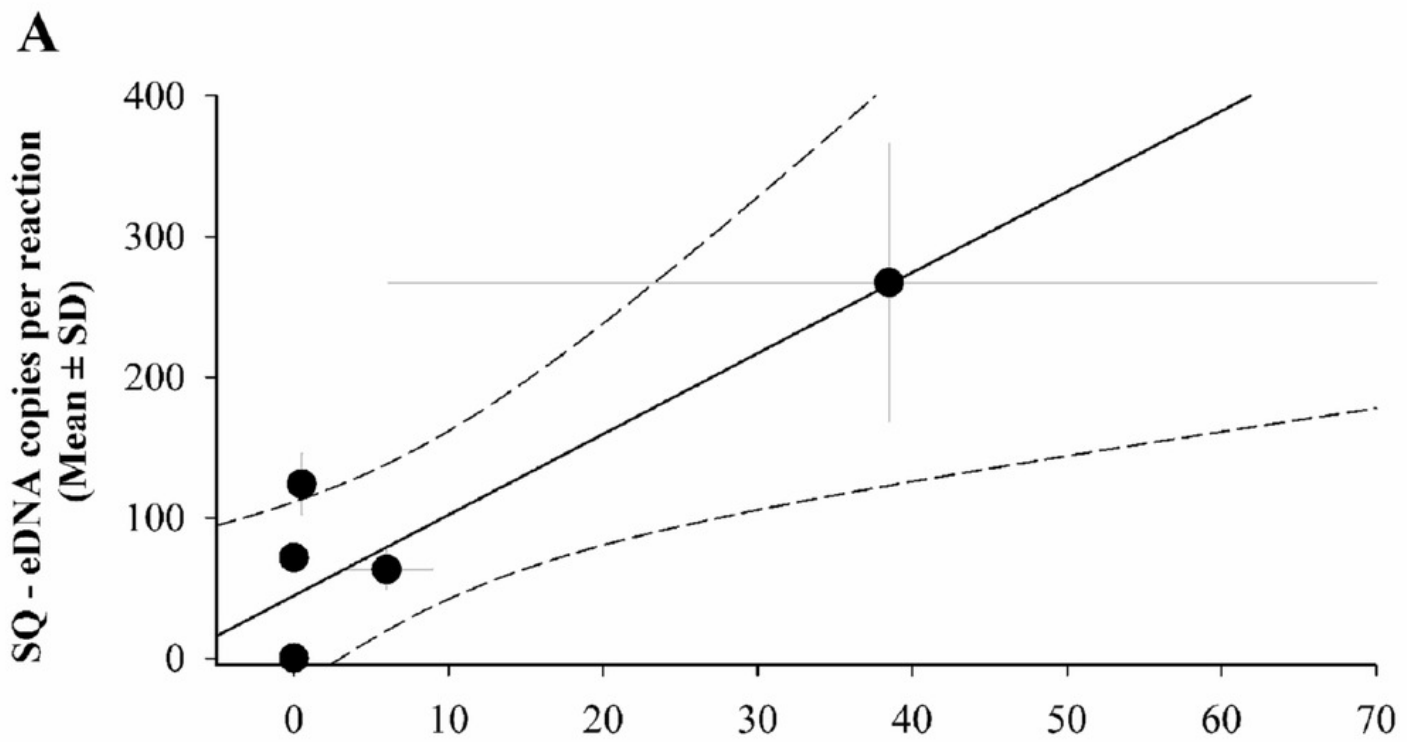

B

Number of New Zealand mud snails (mean \pm SD)

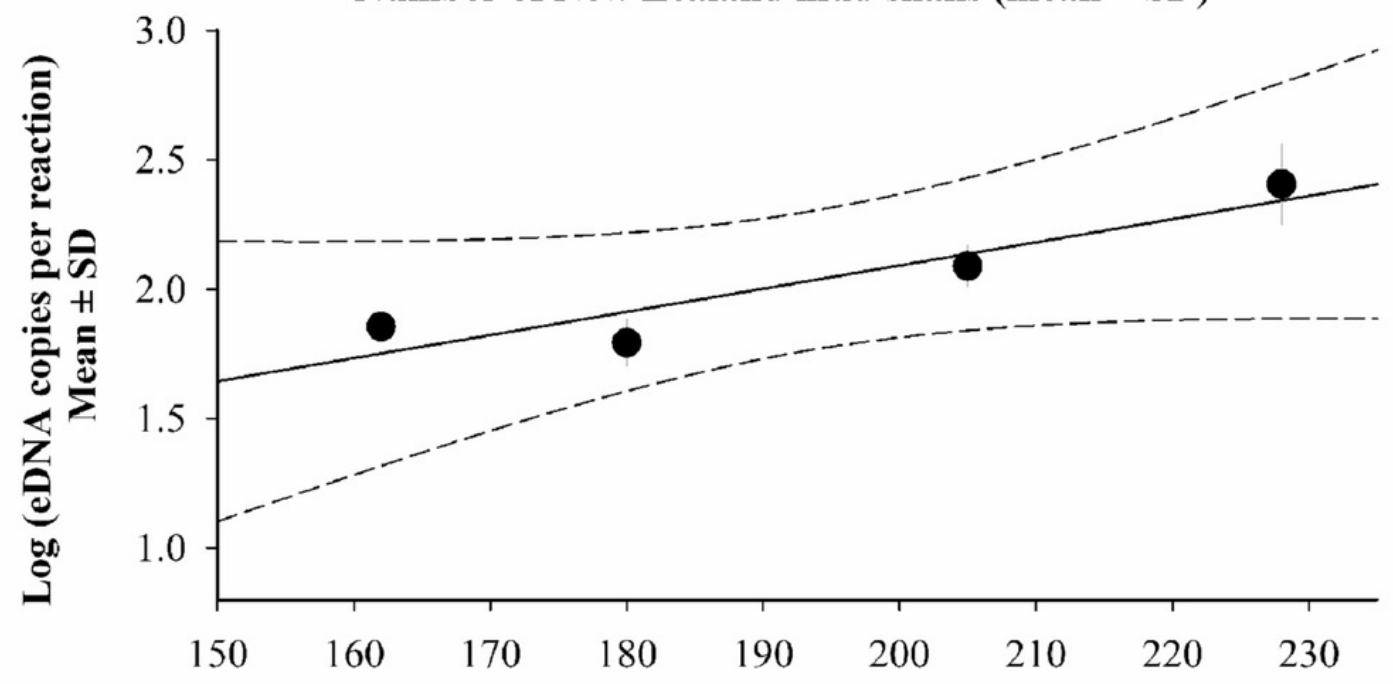

C

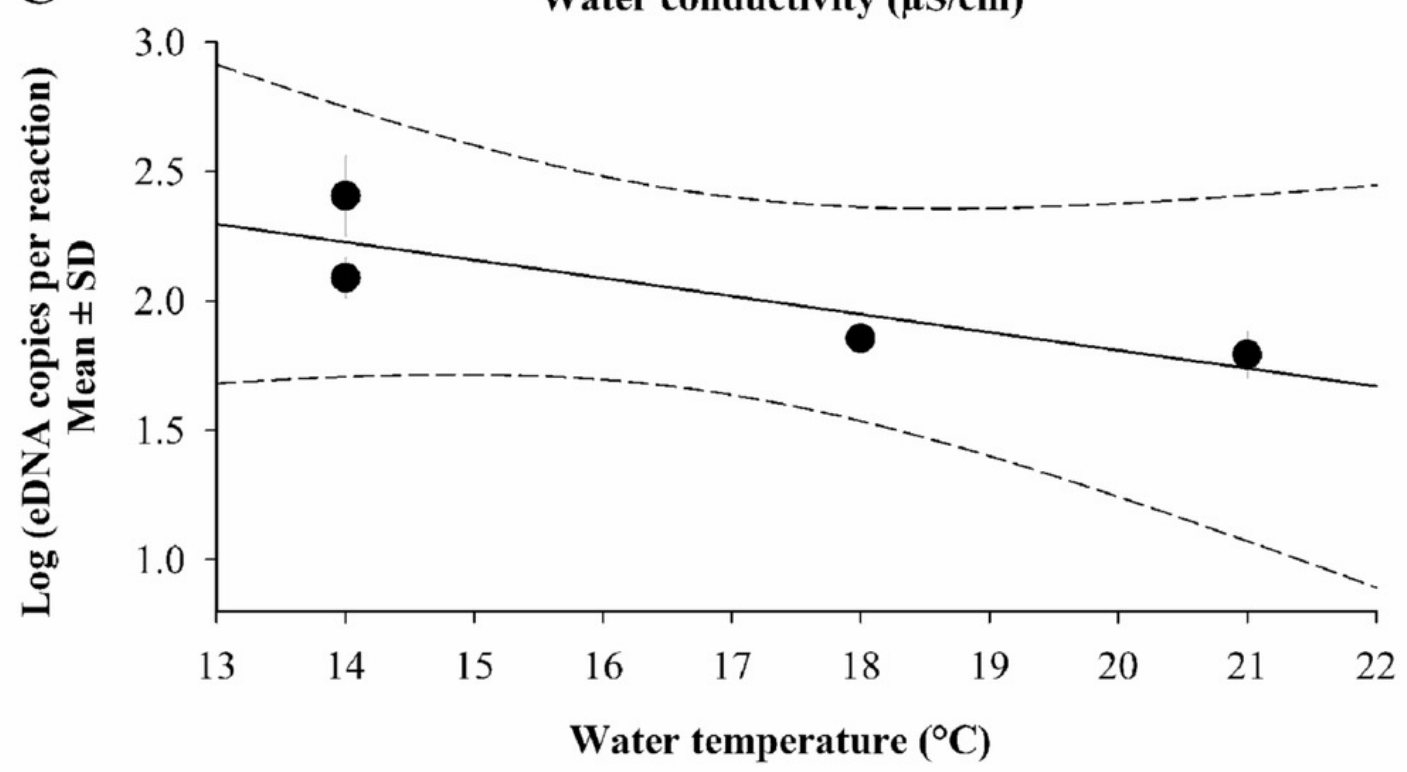




\section{Table $\mathbf{1}$ (on next page)}

Summary of eDNA sample detections and traditional sampling detections $(n=30)$ at multiple sites in Washington. 


\begin{tabular}{|c|c|c|c|c|}
\hline Location & $\begin{array}{c}\text { No. of } \\
\text { snails }\end{array}$ & $\begin{array}{c}\text { Snail capture } \\
\text { sites (\%) }\end{array}$ & $\begin{array}{c}\text { eDNA detected } \\
\text { sites (\%) }\end{array}$ & $\begin{array}{c}\text { eDNA detected sites } \\
\text { where snails were } \\
\text { captured (\%) }\end{array}$ \\
\hline $\begin{array}{c}\text { Burnt Bridge } \\
\text { Creek }\end{array}$ & 29 & $5 / 5(100)$ & $5 / 5(100)$ & $5 / 5(100)$ \\
\hline $\begin{array}{c}\text { Columbia River } \\
\text { (Kalama) }\end{array}$ & 0 & $0 / 5(0)$ & $0 / 5(0)$ & $\mathrm{N} / \mathrm{A}$ \\
\hline Capitol Lake & 0 & $0 / 5(0)$ & $0 / 5(0)$ & $\mathrm{N} / \mathrm{A}$ \\
\hline May Creek & 0 & $0 / 5(0)$ & $2 / 5(40)$ & $0 / 2(0)$ \\
\hline McAleer Creek & 3 & $3 / 5(60)$ & $4 / 5(80)$ & $2 / 4(50)$ \\
\hline Thornton Creek & 165 & $5 / 5(100)$ & $5 / 5(100)$ & $5 / 5(100)$ \\
\hline Total & 197 & $13 / 30(43)$ & $16 / 30(53)$ & $12 / 16(75)$ \\
\hline
\end{tabular}

1

2

3

4

5 